\title{
INNOVATIVE MARKETING OF EMERGING MOSLEM FASHION IN THE PROVINCE OF WEST JAVA INDONESIA
}

\author{
MARIA SUGIAT*1,2, INA PRIMIANA², UMI KALTUM² AND ALDRIN HERWANY2 \\ ${ }^{1}$ Department of Economics and Business, Telkom University, Bandung, West Java, Indonesia. ${ }^{2}$ Department of Economics and \\ Business Universitas Padjajaran, Bandung, West Java, Indonesia.
}

*Corresponding author: mariasugiat@telkomuniversity.ac.id

Submitted final draft: 29 November 2019 Accepted: 14 January 2020

http://doi.org/10.46754/jssm.2020.07.014

\begin{abstract}
Moslem fashion is potentially the next big thing in the retail industry. This research uses a marketing approach to investigate the relationship between marketing innovation and competitive strategy in Moslem fashion online shopping business by engaging in local Small- and Medium Enterprises in West Java. We conducted a quantitative approach by extracting the dimensions of marketing content and technology in marketing innovation. In addition, we looked at the cost leadership, differentiation, and focus on competitive strategy. The author collected the data from 295 respondents who did the survey within three months. The results demonstrate and strongly support the idea that the use of social media in marketing innovation contributes to its competitive strategy, especially in the differentiation strategy. However, the quality of the product becomes the most crucial thing in marketing innovation and has implications for the sustainability of business performance in the Moslem fashion industry in Indonesia.
\end{abstract}

Keywords: Business performance, competitive strategy, Moslem fashion, technology, West Java.

\section{Introduction}

Moslem fashion for women is clothing that covers their entire body, except for the face and palms, which is also known as the hijab. Indonesia is one of the biggest Moslem fashion markets in the world. Trends in Moslem fashion are increasing in recent years; it is used universally for daily activities, not just during religious times. Moslem fashion is used by housewives, entrepreneurs, artists, employees, students, the young generation, and even toddlers. There are also many kinds of attached accessories to make the Moslem outfit more fashionable.

In fact, in the last decades this trend has been promulgated by prestigious female designers who promoted Indonesian Moslem fashion design in international exposures such as Dian Pelangi, Rani Hatta, Khanaan Shamlan, and many more. This trend of fashion styles has spread abroad, such as in the ASEAN countries, the European region, and the United States (Salim \& Ernawati, 2015). In terms of the fashion industry, West Java dominated about $57 \%$ of garment production in Indonesia (Salim
\& Ernawati, 2015). In 2017 this number grew through offline sales $(87 \%)$ and online sales (13\%). According to Jones (2007), Indonesian women have increasingly chosen to adopt a form of Islamic dress due to a rise in Islamic piety. The growing middle class of young women and educated people led these factors to become explicitly anti-fashion frugal and moral critiques. The critics come from the previous generation on Islamic piety expressions which have changed their fashion style from conventional to Moslem fashion style. We should take note that this growing business sector was initiated by Small and Medium Enterprises (SMEs) and Moslem fashion boutiques that grew into large scale producers at a later stage. This paper investigates the link between competitive strategy and marketing innovation.

Gupta et al., (2016) stated that marketing innovation is a consequence of the desire to be a strong competitor in the market. It is also in line with Freeman et al., (2006) that SMEs attempt to demonstrate their ability to innovate in consumer services. This research focuses on the West Java Province due to their strong consumer 
preferences as well as producers' performance. It will contribute to the trend of marketing innovation in the Moslem fashion industry of the Indonesian SMEs. It also provides a profile of Moslem fashion SMEs for policy makers to support market competitiveness.

\section{Business Performance, the Marketing Concept and Marketing Technology}

One of the significant problems of SMEs business development in developing countries is competitiveness (Ahmedova, 2015). Webster (1988) defines that competitiveness of a firm in a market reflects its capability to capture the market through innovative marketing initiatives. Technology is also strongly considered as a basis of value creation which improves efficiency (Porter, 1980). Digital technology is used by marketers to modify individual behaviour, which is a strategy to convince customers to buy their products. Marketers use interactive technologies in order to modify individual behaviour and employ strategies to convince their customers to purchase their products. Pappas et al., (2016) distinguish online shopping behaviour that consists of cognitive and affective perceptions of consumers. This study can be used by SMEs that use digital technology to persuade consumers with cognitive perception in the buying process. Cognitive perception is used to understand consumer profiles to meet consumer preferences with business performance, the marketing concept, and marketing technology. The SMEs use online shopping channels for efficiency, i.e., economic reason rather than affective consumer perception. Economic efficiency results in the benefits of online shopping channels for customers in the form of convenience, time, and cost savings (Pappas et al., 2016).

Business performance is vital for the competitiveness of both buyers and seller firms, Gupta et al., (2016). Marketing innovation through products and processes makes it possible to use resources efficiently to develop competitive advantages. Superior quality, efficiency, and innovation trigger companies to be in the position of the market leader (Hunt et al., 2006; Knight \& Tamer Cavusgil, 2004). The SMEs products must be able to compete with products that are already in the market and well-known brands. When SMEs can provide sustainable products, they are deemed competitive in the market. Marketing contents of online shopping are determined by three dimensions that are the outcomes of interest of online shopping behaviour (i.e., intention to purchase); causal condition of cognitive perceptions (i.e. quality of personalisation, message quality and benefits of personalisation); and causal condition of affective perceptions (i.e. strongly positive emotions, weakly positive emotion, strongly negative emotion, and weakly negative emotion). We only consider two dimensions of online shopping style, which are causal conditions for cognitive perception and online shopping behaviour (Pappas et al., 2016). The last dimension is marketing technology. This marketing innovation can reduce transaction costs for initiating exchanges of knowledge and information as the benefit and risk of online shopping (Gupta et al., 2016 ; Forsythe et al., 2006).

\section{Cost Leadership, Differentiation, and Focus}

Competitiveness is the ability of firms to successfully address opportunities depending upon their ability to contribute to the competitiveness of the partnerships. These factors include mutual understanding about each competency to actualise resources and their market sensing and value creation capabilities (Webster, 1988; Anderson \& Gerbing, 1988). Moreover, (Porter, 1980) has defined three basic sustainable competitive advantages that comprise cost leadership strategy; differentiation strategy, and focus strategy. Cost leadership is the ability of firms to reduce the cost of their participation in planning activities like branding, distribution and opportunity identification in the local market to be identified (Gupta et al., 2016). Reducing cost means improving efficiency to increase productivity forecast and provide assurance related to services, quality, and risk by managers. Zanchettin and Mukherjee, (2017) 
defined product differentiation as innovative activities which generate opportunities to gain profit for both innovators and their competitors. One of the challenging issues in the product differentiation stage is the complexity of interindustry differentiation, how a firm's product can be distinguished from that of other competitors to create their uniqueness for both productivity and market leadership. The last dimension is focused strategy, (Sharma et al., 2018) stated that the refinement and improvement of a firm could lead to advantages, i.e., deeper penetration into an existing customer base. The activities comprise improving production efficiencies by exploiting their current strength and abilities to enhance their performance by higher value creation through improvements in their operational skills and wider accessibility that leads to the firms' resources.

\section{Methods}

The sample of SMEs of Moslem fashion online business collected consists of 295 respondents across West Java Provinces from February until April 2018. The general demographic characteristics of the respondents are shown on Table 1.
There is a large number of female respondents $(82 \%)$ and only $18 \%$ of male. That is because the Moslem fashion business is more related to female's needs, and they understand their market better. The majority $(48 \%)$ of respondents were starting their business in 2011-2015. By the time of the 2018 research, all respondents (295) had used digital technology, and most of respondents had their profits below 7,500 US \$ (68\%) per year in 2018 .

\section{Statistical Analysis}

The data were collected using questionnaires as the instruments and were validated with a constructed test. We tested the results of the questionnaires using reliability test by employing Average Variance Extracted (AVE), Composite Reliability, and Alpha Cronbach test.

Table 2 shows the value of Average Variance Extracted (AVE) on the five variables observed in the study. The AVE value indicates variable validity and fitness. It appears that the AVE values of the five variables ranged from 0.512 to 0.691 . Based on statistical criteria, all variables must be above 0.5 , as all variables must have AVE values above 0.5 . These variables can be considered reliable (Chin \& Brown, 2000).

Table 1: Characteristics of the respondents

\begin{tabular}{llcc}
\hline \multicolumn{1}{c}{ Characteristics } & \multicolumn{1}{c}{ Categories } & N=295 & \% \\
\hline Gender & Male & 53 & 18 \\
& Female & 242 & 82 \\
Starting Business & $1996-2000$ & 9 & 3 \\
& $2001-2005$ & 6 & 2 \\
& $2006-2010$ & 29 & 10 \\
$2011-2015$ & 142 & 48 \\
& $2016-2018$ & 109 & 37 \\
& $<7,500$ US\$ & 201 & 68 \\
Profit in 2018 & $7,501-38,500$ US\$ & 67 & 23 \\
& $38,501-77,000$ US\$ & 21 & 7 \\
& $77,000->$ & 6 & 2 \\
\hline
\end{tabular}


Table 2: Average Variance Extracted (AVE)

\begin{tabular}{cll}
\hline No. & \multicolumn{1}{c}{ Variable } & AVE \\
\hline 1 & Business Performance & 0.691 \\
2 & Competitive Strategy & 0.605 \\
3 & Unique Resources & 0.579 \\
4 & Value Creation & 0.550 \\
5 & Marketing Innovation & 0.512 \\
\hline
\end{tabular}

Table 3: Composite Reliability

\begin{tabular}{clc}
\hline No. & \multicolumn{1}{c}{ Variable } & $\begin{array}{c}\text { Composite } \\
\text { Reliability }\end{array}$ \\
\hline 1 & Marketing Innovation & 0.956 \\
2 & Competitive Strategy & 0.955 \\
3 & Unique Resources & 0.947 \\
4 & Value Creation & 0.940 \\
5 & Business Performance & 0.930 \\
\hline
\end{tabular}

Composite reliability test results show that all values are above 0.9 , which means that all research variables are reliable because they are above 0.900 . The lowest number is recorded in the business performance variable, which is equal to 0.930 , and the highest is recorded in the marketing innovation variable, which is 0.956 . The high composite reliability value in the five variables shows the consistency of the value of each indicator in measuring the construct. The survey results show that the highest number is in marketing innovation hence a vital force in the field of Moslem fashion of SMEs that are based on digital marketing. Certainly, the definition of marketing innovation has an emphasis on online technology-based marketing innovations.

Table 4: Cronbach's Alpha

\begin{tabular}{clc}
\hline No. & Variable & Cronbach's Alpha \\
\hline 1 & Marketing Innovation & 0.951 \\
2 & Competitive Strategy & 0.949 \\
3 & Unique Resources & 0.939 \\
4 & Value Creation & 0.931 \\
5 & Business Performance & 0.912 \\
\hline
\end{tabular}

From Table 4, it can be seen that the Cronbach's alpha values for all variables are above 0.900 , which means that all the variables forming elements are reliable and qualified. The lowest Cronbach Alpha value was recorded in the business performance variable, which is equal to 0.912 , and the highest was recorded in the marketing innovation variable, which is equal to 0.951 . This overall result also shows that the average composite reliability value is higher than the Cronbach's Alpha value. This means that all the questionnaires submitted to Moslem 
fashion SMEs have fulfilled the reliability test. After we passed those tests, then we estimated the data using Structural Equation Modelling (Anderson \& Gerbing, 1988) with Partial Least Square Estimation (PLS). We employed PLS because the data were non-normal distribution due to substantial heterogeneity of SMEs sample across the region of West Java Province. This heterogeneity produces a largely heteroscedastic issue between the sample of SMEs. The skewness and kurtosis are not well performed to produce a normal distribution; this data distribution is against that of Best Linear Un-bias Estimator (BLUE). Therefore, PLS was strongly considered to produce robust estimation rather than OLS estimation or Maximum Likelihood.

\section{Results and Discussion}

Figure 1 illustrates that marketing innovation affects the competing strategy variables of $0.297(29.7 \%)$ with $99 \%$ confidence interval. This coefficient illustrates by any changes in Competitive Strategy variable affected by 0.297 units on changes in marketing innovation by
1 unit. On the left side, marketing innovation is decomposed into several indicators which include the product, marketing concept, and marketing technology. The two dimensions of marketing technology and marketing concept are essential factors in the marketing innovation variable that will enhance SME's of fashion online competitive strategy. These results interpreted as market innovation will affect consumers preferences that change the new look and the expansion of Moslem fashion expressions.

A particular product variable in marketing innovation dimension, i.e., sub-indicators of shape, appearance, packaging or accessories, has significantly affected a coefficient smaller than those of the two previous variables. Therefore, the marketing concept has the highest coefficient, followed by marketing technology, and product, which simultaneously affect the marketing innovation. This result is supported by findings of a study (Ellitan, 2010), which confirmed that marketing innovation is affected by product improvement, process, and technology.

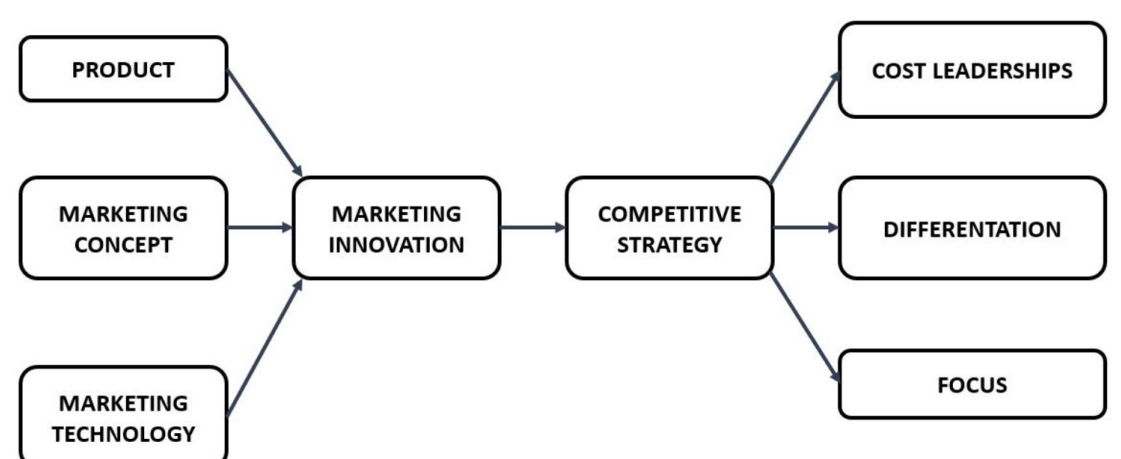

Figure 1: A Research framework 
Table 5: Measurement of Marketing Innovation

\begin{tabular}{|c|c|c|c|}
\hline No & Symbol & Marketing Innovation & $\begin{array}{l}\text { Outer Loading } \\
\text { Factor }\end{array}$ \\
\hline \multicolumn{4}{|c|}{ Product } \\
\hline 1 & IP11 & Create unique product & 0.675 \\
\hline 2 & IP12 & Prioritise product quality & 0.713 \\
\hline 3 & IP13 & Conduct sales promotion & 0.619 \\
\hline 4 & IP14 & Online and offline marketing & 0.644 \\
\hline 5 & IP15 & Utilise market research & 0.698 \\
\hline \multicolumn{4}{|c|}{ Marketing Content } \\
\hline 6 & IP21 & Developing the right marketing message & 0.754 \\
\hline 7 & IP22 & Understanding the consumer appeal & 0.726 \\
\hline 8 & IP23 & Using social media in promotion & 0.807 \\
\hline 9 & IP24 & Using social media in marketing & 0.770 \\
\hline 10 & IP25 & Utilising selebgram in marketing & 0.565 \\
\hline 11 & IP26 & Utilising a brand ambassador in marketing & 0.505 \\
\hline \multicolumn{4}{|c|}{ Technology } \\
\hline 12 & IP31 & Utilising e-commerce marketing & 0.648 \\
\hline 13 & IP310 & $\begin{array}{l}\text { Obtaining information about consumer through digital } \\
\text { media }\end{array}$ & 0.746 \\
\hline 14 & IP32 & Using electronic media in marketing product & 0.774 \\
\hline 15 & IP33 & The influence of social media on sales activities & 0.807 \\
\hline 16 & IP34 & The influence of the use of smart phones to purchase & 0.796 \\
\hline 17 & IP35 & The effectiveness of the product offered online & 0.782 \\
\hline 18 & IP36 & The risk of social impact of negative product review & 0.728 \\
\hline 19 & IP37 & $\begin{array}{l}\text { The use of social media brings the seller closer to the } \\
\text { consumer }\end{array}$ & 0.577 \\
\hline 20 & IP38 & The use of social media has an effect on increasing sales & 0.784 \\
\hline 21 & IP39 & Leveraging influencers in marketing products & 0.793 \\
\hline
\end{tabular}

Malaysia is one of Indonesia's biggest competitors in the fashionable hijab segment. Moslem fashion producers and retailers in the country have already had a head start in terms of marketing by utilising e-commerce and social media platforms, particularly Instagram, to market their products. Naelofar and Mimpikita are two of Malaysian Moslem fashion brands that have successfully gone global. Furthermore, as the number of internet users increases in Indonesia, e-commerce, and social media sites offering Moslem fashion have mushroomed through brands such as Zoya, Hijup, and Hijabenka. Moslem fashion has become a highly sought-after commodity and a rapidly growing industry in Indonesia. On the other side, a competitive strategy was affected by Cost Leadership, Product Differentiation, and Focused Strategy. The coefficient of a decomposed variable is higher than that of Marketing Innovation dimensions, which means direct aggregating of marketing innovations affects through aggregate competitive strategy and decomposed variables of cost leadership, 
Table 6: Measurement of Competitive Strategy

\begin{tabular}{|c|c|c|c|}
\hline No & Symbol & Competitive Strategy & Outer Loading Factor \\
\hline \multicolumn{4}{|c|}{ Cost Leadership } \\
\hline 1 & SB11 & Determining cost efficient operations & 0.763 \\
\hline 2 & SB12 & Determination of a more competitive price & 0.800 \\
\hline 3 & SB13 & $\begin{array}{l}\text { Dissemination of information related Costs customer } \\
\text { with timely, convenient, credible }\end{array}$ & 0.549 \\
\hline 4 & SB14 & $\begin{array}{l}\text { The cost efficiency of online campaign through digital } \\
\text { media }\end{array}$ & 0.662 \\
\hline 5 & SB15 & $\begin{array}{l}\text { The effectiveness of the utilisation of distribution } \\
\text { channels through online media }\end{array}$ & 0.700 \\
\hline \multicolumn{4}{|c|}{ Differentiation } \\
\hline 6 & SB21 & The ability to innovate in the design & 0.801 \\
\hline 7 & SB22 & The ability to innovate in product quality & 0.865 \\
\hline 8 & SB23 & The ability to create different product advantage & 0.834 \\
\hline 9 & SB24 & Variation in product development capability & 0.845 \\
\hline 10 & SB25 & The ability to create ease for customers to get service & 0.830 \\
\hline 11 & SB26 & The ability to implement the latest technology & 0.809 \\
\hline \multicolumn{4}{|l|}{ Focus } \\
\hline 12 & SB31 & Anticipating the speed of market demands & \multirow{3}{*}{$\begin{array}{l}0.767 \\
0.793\end{array}$} \\
\hline 13 & SB32 & Adapting the speed of the latest technology & \\
\hline 14 & SB33 & Speed to meet demand (order) & \\
\hline
\end{tabular}

differentiation, and focused strategy. We imply that in the case of SMEs of Moslem fashion Online Business in the West Java Province, the competitive strategy has been significantly affected by Marketing Innovation.

The research findings have shown that there are product dimensions related to the product quality, marketing concepts through social media, and marketing technology that is in line with the marketing concepts of sales through social media. The 4P marketing concept (product, place, price, and promotion) on digital marketing is dominated by product and promotion in entering the marketplace. Therefore, the concept is no longer significant, and sellers have the freedom to determine prices. In the competitive strategy, differentiation is significant as this dimension relates to the ability of the company to innovate in producing a quality product. The cost leadership and focused strategy are not major dimensions in influencing the competitive strategy of the Moslem fashion business. It is relevant to this study of social media promotion using online technology. The effectiveness and efficiency of online promotions have proven to increase sales.

\section{Conclusion}

Marketing innovation in SMEs of Moslem fashion business has a strong influence in determining a competitive strategy. This research demonstrates marketing innovation, especially on product uniqueness and utilisation of social media that will improve the competitive strategy of SMEs of Moslem fashion online business in West Java. This strategy will support Indonesia's target to be the centre of global Moslem fashion in 2020. The target is attainable since Indonesian Moslem fashion is unique and more diverse compared to those from other countries. The Indonesian government also encourages local Moslem fashion designers and the local community to introduce their brands to global customers. These efforts combined make Indonesia a firm contender to becoming a global Moslem fashion centre and international business and future business for younger generations and its impact on the sustainability of the companies' business. Aggressive marketing and product development must be embedded into the SMEs and MSEs have to ensure that the Moslem fashionable wares will penetrate the large potential market in China, 
India, and the Middle East. These three countries also have the potential of a Moslem population. The possibility of Moslem fashion to become a world fashion trend is not only based on religion but also on the idea that Moslem fashion is part of the modern lifestyle.

\section{Acknowledgements}

The authors would like to especially thank the Ministry of Research, Technology and Higher Education of the Republic of Indonesia, Universitas Padjadjaran, and Telkom University for giving opportunities and financial support for this study. We would like to extend our gratitude to the owners of Moslem Fashion SMEs for providing the data for the completion of this research. Hopefully, this result will help to improve their business performance.

\section{References}

Ahmedova, S. (2015). Factors for increasing the competitiveness of small and mediumsized enterprises (SMEs) in Bulgaria. Procedia - Social and Behavioral Sciences, 195, 1104-1112. https://doi.org/10.1016/j. sbspro.2015.06.155

Anderson, J. C., \& Gerbing, D. W. (1988). Structural equation modeling in practice: A review and recommended two-step approach. Psychological Bulletin, 103(3), 411-423. https://doi.org/10.1037/00332909.103.3.411

Chin, C., \& Brown, D. E. (2000). Learning in science: A comparison of deep and surface approaches. Journal of Research in Science Teaching, 37(2), 109-138. https://doi.org/10.1002/ (SICI)1098-2736(200002)37:2<109::AIDTEA3 $>3.0 . C O ; 2-7$

Ellitan, L. (2010). Strategi inovasi dan kinerja perusahaan manufaktur di Indonesia: Pendekatan model simultan dan model sekuensial. Jurnal Manajemen Maranatha, 6(1), 1-22. https://doi.org/https://doi. org/10.28932/jmm.v6i1.221
Forsythe, S., Liu, C., Shannon, D., \& Gardner, L. C. (2006). Development of a scale to measure the perceived benefits and risks of online shopping. Journal of Interactive Marketing, 20(2), 55-75. https://doi. org/10.1002/dir.20061

Freeman, S., Edwards, R., \& Schroder, B. (2006). How smaller born-global firms use networks and alliances to overcome constraints to rapid internationalization. Journal of International Marketing, 14(3), 33-63.https://doi.org/10.1509/jimk.14.3.33

Gupta, S., Malhotra, N. K., Czinkota, M., \& Foroudi, P. (2016). Marketing innovation: A consequence of competitiveness. Journal of Business Research, 69(12), 5671-5681. https://doi.org/10.1016/j. jbusres.2016.02.042

Hunt, S. D., Arnett, D. B., \& Madhavaram, S. (2006). The explanatory foundations of relationship marketing theory. Journal of Business \& Industrial Marketing, 21(2), 72-87. https://doi. org/10.1108/10610420610651296

Jones, C. (2007). Fashion and faith in urban Indonesia. Fashion Theory, 11(2-3), 211-231. https://doi. org/10.2752/136270407X202763

Knight, G. A., \& Tamer Cavusgil, S. (2004). Erratum: Innovation, organizational capabilities, and the born-global firm. Journal of International Business Studies, 35(4), 334-334. https://doi.org/10.1057/ palgrave.jibs. 8400096

Pappas, I. O., Kourouthanassis, P. E., Giannakos, M. N., \& Chrissikopoulos, V. (2016). Explaining online shopping behavior with fsQCA: The role of cognitive and affective perceptions. Journal of Business Research, 69(2), 794-803. https://doi.org/10.1016/j. jbusres.2015.07.010

Porter, M. E. (1980). Competitive strategy: Techniques for analyzing industries and competitors. New York: Free Press.

Salim, Z., \& Ernawati. (2015). Info komoditi 
pakaian jadi. Jakarta: Badan Pengkajian dan Pengembangan Kebijakan Perdagangan Kementerian Perdagangan Republik Indonesia.

Sharma, R. R., Nguyen, T. K., \& Crick, D. (2018). Exploitation strategy and performance of contract manufacturing exporters: The mediating roles of exploration strategy and marketing capability. Journal of International Management, 24(3), 271283. https://doi.org/10.1016/j.intman.2018. 02.001
Webster, F. E. (1988). The rediscovery of the marketing concept. Business Horizons, 31(3), 29-39. https://doi.org/10.1016/00076813(88)90006-7

Zanchettin, P., \& Mukherjee, A. (2017). Vertical integration and product differentiation. International Journal of Industrial Organization, 55(C), 25-57. https://doi. org/10.1016/j.ijindorg.2017.07.004 